\title{
HELICOBACTER PYLORI INFECTION IN CONNECTIVE TISSUE DISORDERS IS ASSOCIATED WITH HIGH LEVELS OF ANTIBODIES TO MYCOBACTERIAL HSP65 BUT NOT TO HUMAN HSP60
}

(1) László Kalabay MD PhD, (1) Béla Fekete MD DSc, (2) László Czirják MD DSc, (1) Laura Horváth MD, (3) Mohamed R Daha MD DSc, (1) Amarilla Veres MD, (1) Gábor Fónyad MD, (1) Anna Horváth MD, (4) Ágnes Viczián MD, (5) Mahavir Singh PhD, (6) Izabella Hoffer MD PhD, (1) George Füst MD, DSc, (1) László Romics MD DSc, (1) Z. Prohászka MD PhD

(1) $3^{\text {rd }}$ Department of Internal Medicine, Faculty of Medicine, Semmelweis University and Research Group of Metabolism, Genetics and Immunology, Hungarian Academy of Sciences, Budapest, Hungary

(2) $2^{\text {nd }}$ Department of Internal Medicine, Clinical Immunology Unit, University of Pécs, Hungary

(3) Leiden University Medical Center, Department of Nephrology, Leiden, The Netherlands

(4) $2^{\text {nd }}$ Department of Internal Medicine, Faculty of Health Sciences, Semmelweis University, Budapest, Hungary

(5) Lionex Ltd., Braunschweig, Germany

(6) National Blood Transfusion Service, 24. Budapest, Hungary

Corresponding author: László Kalabay MD, PhD, $3^{\text {rd }}$ Department of Internal Medicine, Faculty of Medicine, Semmelweis University, Kútvölgyi út 4., 
Budapest, Hungary, H-1125 Tel.: (36)-1-355-1122, Fax: (36)-1-355-7183, email: kalasz@kut.sote.hu

Key words: Helicobacter pylori infection, Anti-hsp65 antibody, Anti-hsp60 antibody, Systemic autoimmune disease, Undifferentiated connective tissue disease, Systemic sclerosis 


\section{Abstract}

Background: To investigate whether the Helicobacter pylori $(\mathrm{H}$. pylori) status influences levels of antibodies against mycobacterial heat shock protein (hsp) 65 and human hsp60 in systemic autoimmune diseases and studied the concentration of anti-H. pylori antibodies in autoimmune patients and healthy controls.

Materials and Methods: Antibodies against human heat-shock protein hsp60, mycobacterial heat-shock protein hsp65 were analyzed by ELISA. AntiHelicobacter antibodies were determined by enzyme immunoassay. Results: There was markedly higher prevalence of $\mathrm{H}$. pylori infection in undifferentiated connective tissue disease $(82 \%)(n=33)$ and systemic sclerosis $(78 \%)(n=55)$ but not in systemic lupus erythematosus $(n=49)$, polymyositis/dermatomyositis $(n=14)$, rheumatoid arthritis $(n=21)$ or primary Raynaud's syndrome $(n=26)$ compared to controls $(59 \%)(n=349)$. In autoimmune diseases $\mathrm{H}$. pylori infection was associated with elevated levels of anti-hsp65 ( $p=0.008)$ but not of anti-hsp60. Anti-hsp65 levels were significantly higher in H. pylori-infected $(n=129)$ than in uninfected patients $(n=69)(p=$ $0.0007)$.

Conclusions: These findings indicate that in autoimmune diseases the infection with the $\mathrm{H}$. pylori bacterium is associated with increased concentration of antimycobacterial hsp65. 


\section{Introduction}

Helicobacter pylori (H. pylori) is a Gram-negative organism that colonizes the acid-secreting portion of the stomach. It always causes inflammatory histological lesions, which predispose to gastro-duodenal peptic disease, gastric cancer and lymphoma [1, 2, 3].

Several studies have been published on the issue of $H$. pylori and autoimmunity, and almost all of them seemed to give credit to $H$. pylori for influencing the occurrence or course of some autoimmune diseases. In idiopathic thrombocytopenic purpura successful eradication of $H$. pylori resulted in a significant decrease of anti-platelet antibody titers and increase of platelet count [4]. Conversely, no significant differences were found in patients who were treated but not cured. Cross-mimicry mechanisms have been suggested to explain this phenomenon [4]. In rheumatoid arthritis the eradication of $H$. pylori infection led to a significant improvement of all indices of disease activity. No significant changes were observed in controls [5]. In one study about $80 \%$ of patients with primary Sjögren's syndrome (SjS) had antibodies against $H$. pylori [6]. The prevalence was significantly higher than that found in various autoimmune diseases and healthy persons. Increased seroprevalence of $H$. pylori in systemic sclerosis (SSc) has been reported by several groups $[7,8,9$, 10]. Some studies indicated association between $H$. pylori infection and Raynaud's syndrome, speculating that increased levels of cytokines and acute phase reactants, C-reactive protein, and fibrinogen cause vasospasm and 
platelet aggregation $[11,12]$. By contrast, no increased titers of anti-H. pylori antibodies were found in the sera from patients with systemic lupus erythematosus (SLE), rheumatoid arthritis (RA) and polymyositis/ dermatomyositis (PM/DM) [6].

H. pylori sheds extracellular products that elicit local and systemic immune responses that could be responsible for tissue damage [2, 13, 14]. Among these, a $60 \mathrm{kDa}$ protein, belonging to the heat-shock proteins ( $\mathrm{hsp}$ ) seems to play an important role. Since microbial hsp have a high level sequence homology with their mammalian counterparts, and some antigenic determinants may be present in both agent and host proteins, it has been postulated that immune response to $H$. pylori hsp could be involved in the pathogenesis of systemic and organ specific autoimmune diseases $[2,15,16,17]$.

Previously we have reported on the measurement of antibodies against human hsp60 and mycobacterial hsp65 in various autoimmune diseases (SLE, undifferentiated connective tissue disease [UCTD], primary Raynaud's syndrome, [PRS], RA, PM/DM), and healthy blood donors. No significant differences in the anti-hsp60 and anti-hsp65 antibody levels were found between any patient group and the controls except significantly higher anti-hsp concentrations in UCTD (anti-hsp60: $p=0.0094$, anti-hsp65: $p=0.0108$, respectively) [18]. According to several reports serum levels of antibodies against the hsp60 of $H$. pylori are higher in the $H$. pylori-infected than in the uninfected subjects $[2,19,20]$. In addition, titers of these antibodies were 
reduced after H. pylori eradication [21]. Therefore we measured anti-H. pylori antibodies in the sera tested previously by us for anti-hsp antibodies of patients with autoimmune diseases, and assessed whether the $H$. pylori status influences the levels of antibodies to mycobacterial hsp65 and human antihsp60. Another purpose of the present work was to systematically measure of H. pylori antibodies in a high number of patients with different systemic autoimmune diseases and healthy controls.

\section{Methods}

\section{Patients}

All patients of these groups were cared at the $2^{\text {nd }}$ Department of Internal Medicine, University Medical School, Pécs, Hungary. Forty-nine patients with SLE (10 males, 39 females, age: $41.7 \pm 15.4$ years, mean \pm SD), 14 patients with PM/DM (2 males, 12 females, $48.1 \pm 12.7$ years), 21 patients with RA (6 males, 15 females, $46.0 \pm 17.6$ years), 55 patients with SSc (6 males, 49 females, $49.9 \pm 12.1$ years), 33 female patients with UCTD ( $42.5 \pm 11.7$ years) and 26 patients with PRS (6 males, 20 females, $39.4 \pm 10.6$ ) were included in the study. All cases fulfilled the accepted international criteria (A-E) [22, 23, 24, $25,26,27,28,29]$. The study was approved by the local Ethical Committee of the $2^{\text {nd }}$ Department of Internal Medicine. 


\section{$\underline{\text { Healthy controls }}$}

Two groups of healthy blood donors served as controls for the present study.

The first group tested for both anti-H. pylori and anti-hsp antibodies consisted of 192 healthy blood donors (111 males, 81 females, $47.1 \pm 9.8$ years old). Serum samples from 157 other blood donors (117 males, 40 females, $44.4 \pm 9.7$ years old) were tested only for anti-H. pylori antibodies.

\section{Analysis of antibodies to heat-shock proteins}

The levels of IgG-type antibodies reacting with proteins of the chaperonin 60 family (recombinant human hsp60, StressGen, SPP-740, Victoria, Canada; recombinant M. bovis hsp65 [batch MA14, GBF, Braunschweig, Germany, supported by the UNDP/World Bank/WHO Special Program for Research and Training in Tropical Diseases]) was assessed by ELISA. ELISA plates were coated with $0.1 \mu \mathrm{g} /$ well human hsp60 or $M$. bovis hsp65. After washing and blocking (PBS, $0.5 \%$ gelatin) the wells were incubated with $100 \mu$ l of serum samples diluted 1:500 in PBS containing 0.5\% gelatin and 0.05\% Tween 20. Binding of anti-hsp antibodies was determined using $\gamma$-chain specific antihuman IgG peroxidase labelled antibodies (Sigma, St. Louis, USA) and ophenylene-diamine (Sigma) detection system. The optical density was measured at $490 \mathrm{~nm}$ (reference at $620 \mathrm{~nm}$ ) and the means of duplicate wells were calculated [30]. A serial dilution of a control anti-hsp60 rabbit polyclonal antiserum (StressGen, SPA-804, reacting with all hsp tested) was used as standard. Data obtained as optical density values were calculated to arbitrary unit/ml values related to this standard. 


\section{Measurement of the lgG antibodies against Helicobacter pylori}

Titer of anti-H. pylori antibodies was determined by the recomWell Helicobacter IgG test (Mikrogen $\mathrm{GmbH}$, Martinsried, Germany). In this indirect ELISA test recombinant $H$. pylori antigens bound to the solid phase were incubated with 10 $\mu$ of serum samples (1:101 dilution) at $37^{\circ} \mathrm{C}$ for 1 hour. After washing the plates were then incubated with peroxidase-conjugated anti-human IgG antibodies at $37^{\circ} \mathrm{C}$ for 30 minutes followed by washing. The antibody titer was detected by a color reaction using TMB solution at room temperature for 30 minutes, stopped by phosphoric acid. The optical density was measured at 450 $\mathrm{nm}$. The results were expressed as an index value. The cut-off value was based on the study of a large control group. A positive control (= calibrator) in combination with a Factor value was used to determine the OD of cut-off. The value of the Factor was given in the control certificate included with each kit. The OD cut-off in our laboratory was 1.0 . Subjects with a $H$. pylori antibody concentration equal to or below this value were considered as not infected whereas subjects with concentration exceeding cut-off were considered to be infected with the bacterium.

\section{Statistical analysis}

Data were analyzed with GraphPad Prism version 3.0 for Windows (GraphPad Software, San Diego California USA). As the values of antibody to heat-shock proteins and $H$. pylori index values were not normally distributed, nonparametric tests and post hoc tests were used for group comparisons. 
Categorical variables were compared with the $\chi 2$ and Fisher's exact tests. Multiple regression analysis was performed by the SPSS program, version 10.0 (SPSS Inc., Chicago, III, USA).

\section{Results}

Antibodies against $H$. pylori in the sera of patients with different autoimmune diseases and healthy persons

Anti-H. pylori antibody levels were determined in the sera of both groups of healthy blood donors (altogether 349 subjects) and in 198 patients with different autoimmune diseases (UCTD, SSc, SLE, PRS, RA, and PM/DM). Antibody levels to $H$. pylori were significantly $(p<0.0001)$ higher in the group of patients with autoimmune diseases (median [interquartile range] of the index: 2.4 [0.75.4]) as compared to control subjects (1.4 [0.5-3.0]. Since the proportion of females to males was markedly higher in the latter group (174 to 24 as compared to 121 to 227 among the healthy subjects) we compared the antibody levels to $H$. pylori by using multiple regression analysis adjusted to age and gender of the subjects tested. Patients had significantly $(p=0.014)$ higher $H$. pylori indices than the controls even after adjustment to age and gender.

The difference between healthy subjects and patients with autoimmune diseases was due to the significantly higher prevalence of $H$. pylori infection in two diseases: UCTD (82\%) and SSc (78\%) compared with healthy controls (59\%) (Table 1). The median value of the $H$. pylori index was significantly 
higher in these two diseases than in the healthy controls as demonstrated by ANOVA completed with a post hoc test. By contrast, $H$. pylori infection did not occur significantly more frequently and $H$. pylori index was not significantly higher in SLE, PRS, RA or PM/DM patients than in the healthy subjects (Table 1).

$\underline{\text { Relationship between anti-H. pylori antibodies and anti-60 kD heat shock }}$ protein antibodies in the sera of patients with autoimmune diseases In the whole group of 198 patients with different autoimmune diseases the serum concentration (index) of anti-H. pylori antibodies exhibited a highly significant positive correlation with antibodies against $M$. bovis hsp65 $(r=0.335$, $p<0.0001$ ) whereas no correlation with serum levels of antibodies against human hsp60 was found $(r=0.056, p=0.441)$. By contrast, in the sera of healthy controls there was a weak but highly significant positive correlation between the levels of anti-hsp60 and anti-H. pylori antibodies (data not shown).

When patients and controls were divided into two groups (those with a $H$. pylori index equal to or exceeding 1.0 (considered infected with the bacterium) and those with a $H$. pylori index $<1.0$ considered to be not infected) marked differences were found in the levels of antibodies to mycobacterial hsp65 (Table 2). The levels of these antibodies were significantly $(p=0.0007)$ lower in the sera of the 69 not infected patients than in those from the $129 \mathrm{H}$. pyloriinfected patients whereas no difference in the anti-hsp65 antibody concentration was found between infected and not infected healthy controls 
(Table 2). By contrast, median serum concentration of anti-hsp60 antibodies did not differ between $H$. pylori-infected and not infected patients whereas a slight but significant difference was observed in the group of healthy controls (Table 2).

Significant differences between the patients and controls were found only In the H. pylori positive group: anti-hsp65 levels were almost 1.5 times higher in the patients than in the controls $(p=0.008)$ whereas in the $H$. pylori negative group anti-hsp65 antibody concentration was about the same in the healthy subjects and the patients. No differences in the anti-hsp60 antibody levels were found between patients and controls in either group (Table 2).

By using ANOVA, we did not find significant differences among groups with different autoimmune diseases either in the levels of anti-hsp60 or anti-hsp65 antibodies (data not shown).

\section{Discussions}

We have studied two questions: $\mathrm{i}$ ) is there any difference in the frequency of $H$. pylori infection between patients with different autoimmune diseases and healthy persons, and ii) does infection with $H$. pylori influence the occurrence of antibodies against human and mycobacterial hsp in the same patients and healthy subjects? 
As for the frequency of $H$. pylori infection, patients with autoimmune diseases as a whole had significantly higher average lgG anti-H. pylori levels than healthy controls. This difference, however, could be solely due to an increased serum concentration in UCTD and SSc. More importantly, the frequency of high $(\geq 1.0)$ anti-H. pylori indices, (considered as the sign of infection), was higher than those in the healthy control group only in these two diseases. In accordance with previous results the patients with SLE, PRS, RA and PM/DM did not differ from the healthy group in this respect either [9]. Thus our present findings indicate that the frequency of $H$. pylori-infected subjects exceed that in the healthy normal population only in some autoimmune diseases.

Of particular relevance is the preferential occurrence of $H$. pylori infection in UCTD that refers to diseases in evolution toward particular differentiated particular connective tissue disorders including SSc. To our best knowledge, no data on the frequency of anti-H. pylori antibodies in this disease have been published yet. Further studies are needed to evaluate the possible diagnostic and prognostic significance of $H$. pylori infection in such cases. In accordance with our results several recent findings indicate increased rate of $H$. pylori infection in patients with SSc $[7,8,9,10]$. The preferential occurrence of $H$. pylori infection in SSc may be explained in two ways. First, an increased prevalence of $H$. pylori infection might be favored by the disturbed gastrointestinal motility, a clinical phenomenon well known in patients with SSc. The second explanation may be that $H$. pylori infection and the immunological mechanisms operative in the course of SSc may be related. 
H. pylori-associated hsp60, human hsp60 and mycobacterial hsp65 are members of the $60-\mathrm{kD}$ family of heat shock proteins, they are believed to share high sequence homology. Thus potential exists for cross-reaction of antibodies directed against these proteins $[16,20,31,32,33,34]$. Several recent observations indicate that the titer of antibodies against $H$. pylori hsp60 is significantly higher in H. pylori-infected than in the not infected subjects [2, 19, 20]. Furthermore, the titration of these antibodies can be used for early serological monitoring of $H$. pylori eradication treatment [21]. Only scarce data are, however, available on the influence of $H$. pylori infection on serum concentration of antibodies against other members of the $60 \mathrm{kD}$ hsp family [31, 35]. To our best knowledge no such study has been performed in patients with autoimmune diseases.

By using sensitive ELISA methods that were found to be suitable to measure the serum concentrations and study the properties of antibodies against different members of $60 \mathrm{kD}$ hsp [30,36,37] we obtained only weak differences between $H$. pylori-infected and not infected healthy individuals in the levels of anti-human hsp60 and anti-mycobacterial hsp65 IgG antibodies [18]. No influence of $H$. pylori infection on the serum concentration of these antibodies has been found previously whereas IgA type antibodies to hsp60 and hsp65 were elevated in patients with atrophy compared to $H$. pylori negative controls [35]. Sharma et al - in accordance with our present findings - found IgG antibodies recognizing human hsp60 that could be detected by immunoblotting 
in $H$. pylori-infected persons but found no difference between $H$. pylori-infected and not infected individuals in antibodies to $M$. bovis hsp65 [31].

The normal level of anti-hsp60 antibodies in patients with autoimmune diseases supports our recent hypothesis on the regulation of the autoantibodies against human hsp60 [36]. According to this hypothesis anti-hsp60 antibodies can be considered as bona fide natural autoantibodies. Our unpublished observations indicate that the level of these antibodies is constant for years and even decades as that of other natural autoantibodies [38, 39]. If this assumption is true, polyclonal B cell activation, characteristic for some autoimmune disease, such as SLE is expected to have no influence on their serum concentration. Our present findings are compatible with this assumption as is our previous observation on the normal anti-hsp60 antibody levels in HIV-infection, a disease that is also associated with polyclonal B cell activation [40].

In contrast to anti-hsp60, serum concentration of antibodies against mycobacterial hsp65 correlated to that of anti-H. pylori antibodies in patients with autoimmune diseases. Moreover, in these diseases anti-hsp65 antibodies were found in significantly higher titers in $\mathrm{H}$. pylori-infected than in not infected patients. Human hsp60 and mycobacterial hsp65 share several common epitopes therefore anti-hsp60 and anti-hsp65 antibodies cross-react with each other. However, the overlap between the two proteins is only partial, they have different epitope specificities and complement activating abilities [30]. Since anti-mycobacterial hsp65 represents antibody against bacterial hsp combined 
infection with $H$. pylori and some other bacteria might contribute to the observed results.

There are marked differences in the epitope specificity between the $H$. pylori associated hsp60, other bacterial $60 \mathrm{kD}$ hsps and human hsp60 as well. The amino acid sequences of two regions (residues 181 to 204 and 204 to 229) on H. pylori hsp60 were different from the amino acid sequences of other bacterial hsp60s, whereas the amino acid region of residues 189 to 203 on H. pylori hsp60 is conserved among several bacterial hsp60s and human hsp60 [21]. Our present findings indicate that a part of the antibodies reacting with mycobacterial hsp65 represent antibodies against cross-reactive epitopes between mycobacterial hsp65 and H.pylori-associated hsp60 and their elevated titer in $\mathrm{H}$. pylori-infected patients reflects high serum concentration of antibodies against $H$. pylori hsp60 [2, 19, 20]. Increased formation of these antibodies in H. pylori-infected patients with some autoimmune diseases may be a part of the immune dysregulation characteristic for the given disease. More studies are needed for a better understanding of the development and the possible pathological significance of anti-hsp antibodies with a large array of specificity in autoimmune diseases.

\section{Acknowledgements}

This work was supported by following grants: FKFP 0106/2000, FKFP 0138/2001, OTKA F29030, and OTKA T025449. Z.P. is a Bolyai János research fellow. 


\section{References}

1. Blaser MJ. Epidemiology and pathophysiology of Campylobacter pylori infections. Rev Infect Dis 1990; 12(suppl 1):S99-S106.

2. Macchia G, Massone A, Burroni D, Covacci A, Censini S, Rappuoli R. The hsp60 protein of Helicobacter pylori: structure and immune response in patients with gastroduodenal diseases. Mol Microbiol 1993; 3:645-52.

3. Parsonnet J, Hansen S, Rodriguez I, Gelb AB, Warnke RA, Jellum E, Orentreich N, Vogelman SH, Friedman GD. Helicobacter pylori infection and gastric lymphoma N Engl J Med 1994; 330:1267-71.

4. Gasbarrini A, Franceschi F, Tartaglione R, Landolfi R, Pola P, Gasbarrini G. Regression of autoimmune thrombocytopenia after eradication of Helicobacter pylori. 1998; Lancet 352:858.

5. Zentilin P, Savarino V, Garmero A, Accardo S, Seriolo B. Is Helicobacter pylori infection a risk factor for disease severity in rheumatoid arthritis? Gastroenterology 1999; 116:503-4

6. Aragona P, Magazzu G, Macchia G, Bartolone S, Di Pasquale G, Vitali C, Ferreri G. Presence of antibodies against Helicobacter pylori and its heat shock protein 60 in the serum of patients with Sjögren's syndrome J Rheumatol 1999; 26:1306-11.

7. Reinauer S, Goerz G, Ruzicka T, Susanto F, Humfeld S, Reinauer H. Helicobacter pylori in patients with systemic sclerosis: detection with the 13urea breath test and eradication. Acta Derm-Venereol 1994; 74:361-3.

8. Fujimoto M, Sato S, Ihn H, Takehara K. Autoantibodies to the heat-shock protein hsp73 in localized scleroderma. Arch Dermal Res 1995; 287:581-5. 
9. Showji Y, Nozawa R, Sato K, Suzuki H. Seroprevalence of Helicobacter pylori infection in patients with connective tissue diseases. Microbiol Immunol 1996; 40:499-503.

10. Yazawa N, Fujimoto M, Kikuchi K, Kubo M, Ihn H, Sato S, Tamaki T, Tamaki K. High seroprevalence of Helicobacter pylori infection in patients with systemic sclerosis: association with oesophageal involvement. J. Rheumatol 1998; 4:650-3.

11. Gasbarrini A, Massari I, Serrichio M, Tondi P, De Luca A, Franceschi F, Ojetti V, DalLago A, Flore R, Santoliquido A, Gasbarrini G, Pola P. Helicobacter pylori eradication ameliorates primary Raynaud's phenomenon. Digest Dis Sci 1998; 43:641-5.

12. Realdi G, Dore MP, Fastame L. Extradigestive manifestations of Helicobacter pylori infection. Fact and fiction. Digest Dis Sci 1999; 44:22936.

13. Lee A, Fox J, Hazell SS. Pathogenicity of Helicobacter pylori: a perspective. Infect Immun 1993; 61:1601-10.

14. Negrini R, Lisato L, Zanella I, Cavazzini L, Gullini S, Villanacci V, Poiesi C, Albertini A, Ghielmi S. Helicobacter pylori infection induces antibodies crossreacting with human gastric mucosa. Gastroenterology 1991; 101:437-45.

15. Yang XD, Feige $U$. Heat shock protein in autoimmune disease. From causative antigen to specific therapy? Experientia 1992; 48:650-6.

16. Winfield JB, Jarjour W: Do stress proteins play a role in arthritis and autoimmunity? Immunol Rev 1991; 121:193-220. 
17. Dhillon VB, McCallum S, Norton P, Twomey BM, Erkeller-Yuksel F, Lydyard $P$, Isenberg DA, Latchman DS. Differential heat shock protein overexpression and its clinical relevance in systemic lupus erythematosus. Ann Rheum Dis 1993; 52:436-42.

18. Horváth L, Czirják L, Fekete B, Jakab L, Prohászka Z, Cervenak L, Romics L, Singh M, Daha MR, Füst G. Levels of antibodies against C1q and $60 \mathrm{kD}$ family of heat shock proteins in the sera of patients with various autoimmune diseases. Immunol Lett 2001; 75:103-9.

19. Perez-Perez GI, Brown WR, Cover TL, Dunn BE, Cao P, Blaser MJ. Correlation between serological and mucosal inflammatory responses to Helicobacter pylori. Clin Diagn Lab Immun 1994; 1:325-9.

20. Yamaguchi $H$, Osaki T, Kai M, Taguchi $H$, Kamiya S. Immune response against a cross-reactive epitope on the heat shock protein 60 homologue of Helicobacter pylori. Infect Immun 2000; 68:3448-54.

21. Yunoki N, Yokota K, Mizuno M, Kawahara Y, Adachi M, Okada H, Hayashi S Hirai Y, Oguma K, Tsuji T. Antibody to heat shock protein can be used for early serological monitoring of Helicobacter pylori eradication treatment Clin Diagn Lab Immun 2000; 7:574-7.

22. LeRoy EC, Black C, Fleischmajer R, Jablonska S, Krieg T, Medsger TA, Rowell N, Wollheim F. Scleroderma (systemic sclerosis): classification, subset, and pathogenesis. J Rheumol 1988; 15:202-5.

23. Subcommittee for Scleroderma Criteria of the American Rheumatism Association Diagnostic and Therapeutic Criteria Committee. Preliminary 
criteria for the classification of systemic sclerosis (scleroderma). Arthritis Rheum 1980; 23:581-90.

24. Alarcon GS, Williams GV, Singer JZ, Steen VD, Clegg DO, Paulus HE, Billingsley LM, Luggen ME, Polisson RP, Wilkens RF. Early undifferentiated connective tissue disease. I. Early clinical manifestation in a large cohort of patients with undifferentiated connective tissue diseases compared with cohorts of well-established connective tissue disease. J Rheumatol 1991; 18:1332-9.

25. LeRoy EC, Metsger TA Jr. Raynaud's phenomenon: a proposal for classification. Clin Exp Rheumatol 1992; 10:485-8.

26. Arnett FC, Edworthy SM, Bloch DA, McShane DJ, Fries JF, Cooper NS, Healey LA, Kaplan SR, Liang MH, Luthra HS. The American Rheumatism Association 1987 revised criteria for the classification of rheumatoid arthritis. Arthritis Rheum 1988; 31:315-24.

27. Tan EM, Cohen AS, Fries JF, Masi AT, McShane DJ, Rothfiels NF, Schaller JG, Talal N, Winchester RJ. The 1982 revised criteria for the classification of systemic lupus erythematosus. Arthritis Rheum 1982; 25:1271-7.

28. Bohan A, Peter JB. Polymyositis and dermatomyositis. Parts 1 and 2. N Engl J Med 1975; 344-7, 403-7.

29. Molnár I, Czirják L. Inhibitory effect of sera on the thyroid 5'-deiodinase activity in systemic sclerosis. Clin Exp Rheumatol 2000; 18:719-24.

30. Prohászka Z, Duba J, Lakos G, Kiss E, Varga L, Jánoskuti L, Császár A, Karádi I, Nagy K, Singh M, Romics L, Füst G. Antibodies against human 
hsp60 and mycobacterial hsp65 differ in their antigen specificity and complement activating ability. Int Immunol 1999; 11:1363-70.

31. Sharma SA, Miller GG, Peek RA Jr, Perez-Perez G, Blaser MJ. T-cell, antibody, and cytokine responses to homologues of the 60-kilodalton heat shock protein in Helicobacter pylori infection. Clin Diagn Lab Immun 1997; 4:440-6.

32. Jindal S, Dudani AK, Singh B, Harley CB, Gupta RS. Primary structure of a human mitochondrial protein homologous to the bacterial and plant chaperonins and to the 65 kilodalton mycobacterial antigen. Mol Cell Biol 1989: 9:2279-83.

33. Dunn BE, Roop RM, Sung CC, Sharma SA, Perez-Perez GI, Blaser MJ. Identification and purification of a cpn60 heat shock protein homologue from Helicobacter pylori. Infect Immun 1992; 60:212-7.

34. Enders KW, Thompson SA, Perez-Perez GI Kansau I, van der Ende A, Labigne A, Sung JY, Chung SCS, Blaser MJ. Helicobacter pylori heat shock protein A: serologic responses and genetic diversity. Clin Diagn Lab Immun 1999; 6:377-82.

35. Barton SG, Winrow VR, Rampton DS, Crabtree JE, Beales ILP, Calam J. Circulating antibodies to the $60-\mathrm{kD}$ heat shock protein (hsp) family in patients with Helicobacter pylori infection Clin Exp Immunol 1998; 112:4904.

36. Prohászka Z, Duba J, Horváth L Császár A, Karádi I, Szebeni A, Singh M, Fekete B, Romics L, Füst G. Comparative study on antibodies to human and bacterial $60 \mathrm{kD}$ heat shock proteins in a large cohort of patients with 
coronary heart disease and healthy subjects. Eur J Clin Invest 2001; $31: 285-92$.

37. Burian K, Kis Z, Virok D, Endresz V, Prohászka Z, Duba J, Berencsik K, Boda K, Horváth L, Romics L, Füst G, Gönczöl E. Independent and joint effects of antibodies to human heat-shock protein 60 and Chlamydia infection in the development of coronary atherosclerosis. Circulation 2001; 103:1503-8.

38. Rodman TC, To SE, Sullivan JJ, Winston R. Innate natural antibodies. Primary roles indicated by specific epitopes. Hum Immunol 1997; 55:87-95.

39. Lacroix-Desmazes S, Mouthon L, Kaveri SV, Kazatchkine MD, Weksler ME. Stability of natural self-reactive antibody repertoires during aging. J Clin Immunol 1999; 19:26-34.

40. Prohászka Z, Bánhegyi D. Ujhelyi E, Karádi I, Füst G. Antibodies against 60$\mathrm{kDa}$ heat-shock proteins in human immunodeficiency virus infection. Ann NY Acad Sci 1998; 851:94-8. 
Table 1

Association of different autoimmune diseases and infection with Helicobacter pylori

\begin{tabular}{|l|c|c|}
\hline \multicolumn{1}{|c|}{ Patients with } & $\begin{array}{c}\text { Number of } \\
\text { subjects }\end{array}$ & $\begin{array}{c}\text { H. pylori index, median } \\
\text { (interquartile range) }\end{array}$ \\
& $\begin{array}{c}\text { (H. pylori } \\
\text { prevalence } \%)^{+}\end{array}$ \\
\hline Healthy controls & $349 / 206(59 \%)$ & $1.50(0.50-3.95)$ \\
\hline Undifferentiated connective tissue & $33 / 27(82 \%)^{*}$ & $3.40(1.10-6.00)^{*}$ \\
\hline disease (UCTD) & & \\
\hline Systemic sclerosis (SSc) & & \\
\hline Systemic lupus erythematosus (SLE) & $49 / 28(57 \%)$ & $1.50(0.60-4.40)$ \\
\hline Primary Raynaud's syndrome (PRS) & $26 / 12(46 \%)$ & $2.25(0.60-5.35)$ \\
\hline Rheumatoid arthritis (RA) & $21 / 11(52 \%)$ & $1.65(0.60-4.75)$ \\
\hline Polymyositis/dermatomyositis & $14 / 11(79 \%)$ & $2.10(0.50-4.35)$ \\
\hline PM/DM) & & \\
\hline
\end{tabular}

${ }^{+} H$. pylori index $>1,{ }^{*} \mathrm{p}<0.05,{ }^{* *} \mathrm{p}<0.01$, Fisher's exact test and Dunn post hoc test for the column 1 and 2, respectively 
Table 2

Comparison of the serum concentration of the antibodies to mycobacterial hsp65 and human hsp60 in patients with autoimmune diseases and healthy subjects infected or not infected with Helicobacter pylori

\begin{tabular}{|c|c|c|c|c|c|c|}
\hline & \multicolumn{3}{|c|}{$\begin{array}{l}\text { Anti-hsp60, median (interquartile } \\
\text { range) (number of subjects) }\end{array}$} & \multicolumn{3}{|c|}{$\begin{array}{l}\text { Anti-hsp65, median (interquartile } \\
\text { range) (number of subjects) }\end{array}$} \\
\hline & $\begin{array}{l}\text { Healthy } \\
\text { subjects }\end{array}$ & $\begin{array}{l}\text { Patients with } \\
\text { autoimmune } \\
\text { diseases }\end{array}$ & $\begin{array}{l}P \\
\text { value* }\end{array}$ & $\begin{array}{l}\text { Healthy } \\
\text { subjects }\end{array}$ & $\begin{array}{l}\text { Patients with } \\
\text { autoimmune } \\
\text { diseases }\end{array}$ & $\mathrm{P}$ value* \\
\hline $\begin{array}{c}H \\
\text { pylori } \\
\text { index } \leq \\
1.0\end{array}$ & $\begin{array}{l}87.7(50.2- \\
140.5)(79)\end{array}$ & $\begin{array}{c}93.1(64.7- \\
164.9) \\
(69)\end{array}$ & 0.340 & $\begin{array}{l}9.8(4.6- \\
21.5)(79)\end{array}$ & $\begin{array}{c}10.4(4.7- \\
17.0) \\
(69)\end{array}$ & 0.949 \\
\hline $\begin{array}{c}H \\
\text { pylori } \\
\text { index }> \\
1.0\end{array}$ & $\begin{array}{l}116.3(71.1- \\
179.4)(113)\end{array}$ & $\begin{array}{c}119.2(72.3- \\
202.5) \\
(129)\end{array}$ & 0.533 & $\begin{array}{c}11.3(4.9- \\
24.2) \\
(113)\end{array}$ & $\begin{array}{c}15.8(8.4- \\
31.3)(129) \\
(129)\end{array}$ & 0.008 \\
\hline$P$ value & 0.024 & 0.182 & - & 0.473 & 0.0007 & - \\
\hline Total & $\begin{array}{l}100.8(64.4- \\
170.9)(192)\end{array}$ & $\begin{array}{l}110.6(66.3- \\
199.6)(198)\end{array}$ & 0.187 & $\begin{array}{c}10.7(4.9- \\
21.7) \\
(192)\end{array}$ & $\begin{array}{l}12.7(7.2- \\
25.5)(198)\end{array}$ & 0.023 \\
\hline
\end{tabular}

